\title{
Introduction: War and Memory in Russia, Ukraine, and Belarus
}

\author{
Julie Fedor, Simon Lewis and Tatiana Zhurzhenko
}

Julie Fedor's research for this essay was supported under the Australian Research Council's Discovery Early Career Research Awards (DECRA) funding scheme (project DE150100838). The Open Access fee was also covered by the same grant. The views expressed herein are those of the author and are not necessarily those of the Australian Research Council.

At the beginning of the war in the Donbas, in early June 2014, long before Russia had filled the region with weapons, pro-Russian separatists in the small town of Konstantynivka in the Donetsk region told journalists

J. Fedor $(\triangle)$

The University of Melbourne, Melbourne, VIC, Australia

e-mail: julie.fedor@unimelb.edu.au

S. Lewis

Institute for East European Studies, Garystraße 55, 14195 Berlin, Germany

e-mail: Simon.lewis@fu-berlin.de

T. Zhurzhenko

Institute for Human Sciences (IWM), Spittelauer Lände 3,

1090 Vienna, Austria

e-mail: zhurzhenko@iwm.at

(C) The Author(s) 2017

J. Fedor et al. (eds.), War and Memory in Russia, Ukraine and Belarus, DOI 10.1007/978-3-319-66523-8_1 
that the tank they were using against the Ukrainian army had been taken down from the plinth of a World War II memorial in a local park, repaired, refueled, and "brought back to life" (Segodnia 2014). Regardless of whether the story is true, the metaphor is powerful-it suggests that the ghosts of a war that ended seventy years ago are easily evoked.

This edited collection contributes to the current vivid multidisciplinary debate on memory politics in Eastern Europe, focusing on the re-narration and political instrumentalization of World War II memories in the post-Soviet context. At the same time, our book has a distinctive geographic focus: we concentrate on the three Slavic countries of postSoviet Eastern Europe-Russia, Ukraine, and Belarus. Together they comprise the epicenter of Soviet war suffering, and the heartland of the Soviet war myth. In all three countries, memories of the war have been central in post-Soviet identity making; yet they demonstrate very different trajectories of nation-building and memory regimes. Contributions to our volume give insight into the persistence of the Soviet commemorative culture of World War II and the myth of the Great Patriotic War in the post-Soviet space. Yet the volume also demonstrates that due to various geopolitical, cultural, and historical reasons the political uses of World War II in post-Soviet Ukraine, Russia, and Belarus differ significantly, with important ramifications for future developments in the region and beyond.

The enduring prominence of World War II as a key theme in the national narratives of our target countries is unsurprising given the special intensity and scale of war suffering in this part of Europe. The war experience was especially traumatic here, where the population experienced unprecedented human losses, the destruction of the basic infrastructure, repressions under two occupational regimes, mass murder, deportations and ethnic cleansings. In this part of Europe, which (together with Poland) Timothy Snyder (2010) called the "Bloodlands," the brutalities of the war itself can hardly be separated from the mass crimes of Hitler's and Stalin's regimes. Although the scale of suffering was highest in Ukraine and Belarus, where the entire territory was occupied and devastated, in the Western optic these two countries tend to be subsumed under the sign of "Russia" and disappear from view. In this volume, we set out to offer a corrective to this view by broadening the lens beyond the Russian perspective.

The contributors to this book document the explosion of new memory practices, agents, symbols, and narratives that is currently underway 
in the Russia-Ukraine-Belarus triangle. At one level, these should be read in the context of an important event that we are presently witnessing: the passing of the last living World War II veterans. Stephen M. Norris has described how the 2010 Victory Day was framed by some Russian media as "The Last Parade" of the veterans and the end of the "living memory" of the war (Norris 2011). With the passing of this generation, the war memory is making the transition from the realm of communicative memory to that of cultural memory, to use Jan Assmann's influential terms (2008). Assmann distinguished between communicative memory, based on an exchange of direct, biographical experience, and cultural memory, which is "a kind of institution. It is exteriorized, objectified, and stored away in symbolic forms that, unlike the sounds of words or the sight of gestures, are stable and situation-transcendent" (116-117). It is precisely this moment of transition that is reflected throughout the contributions to the book, documenting as they do the compulsive search for new forms of remembering, manifested in the war theme's renewed prominence in mass culture, and in both public and private life, and in the production of new and reconstituted myths. At this moment of anxiety, as the direct bearers of World War II memory pass away, the memory of the war becomes if anything even more ever-present, and in many ways more unstable, in Russia, Belarus, and Ukraine.

The proliferation of new war monuments, and of public calls to keep the memory of war "alive," hide a widespread anxiety related to the current moment of generational change and to entering a new world without the "war generation" whose moral authority was almost univocally accepted in fragmented and politically polarized post-Soviet societies. Many of the new practices explored in the book can be seen as part of what Elena Rozhdestvenskaya has called the "hyper-exploitation of the past Victory" which "leads to the constant making-present of the war experience, to the unending search for new methods of commemoration, so as to further extend the life of this event" (Rozhdestvenskaya 2015). ${ }^{1}$ David R. Marples (2014: ix) has asked: what consequences will the passing of the last veterans have for the ongoing viability of state reliance on the war myth? These consequences are still unfolding, but the contributors to this book go some way towards answering this question.

The book is a late fruit of the international research project Memory at War: Cultural Dynamics in Poland, Russia, and Ukraine, led by Alexander Etkind and based at the University of Cambridge in 
2010-2013, and draws on the international symposium "Narratives of Suffering in Post-Cold War Europe: The Second World War in Transnational Contexts," organized by the Helsinki team of the project at the Aleksanteri Institute, University of Helsinki in September 2012.2 The production of this volume coincided with (and was delayed by) dramatic events in our region, as discursive memory wars merged with and fueled a real war in Ukraine, following the events of the Euromaidan (2013-2014). These events reconfigured lives, societies, identities, and politics in our region, first of all in Ukraine and Russia. These changes have also reconfigured the field of our research. The book does not focus on these recent changes, although most chapters do address them (and we discuss them in a dedicated section of this introduction).

Instead, the book offers a deeper and broader contextualization of the politics of war memory within the Russia-Ukraine-Belarus triangle. We present here a collection of empirically rich case studies exploring political, social and cultural dimensions, and on multiple scales, from the local-Sevastopol, Narva, Karelia; to the national; and through to the transnational, since the cultures of remembrance analyzed here are not limited by state borders. ${ }^{3}$ Several of the chapters trace back the evolution of these memory cultures and narratives since the early 1990s, and some go back further still. In this way we set out to add historical depth to our understanding of the present situation in the region, and also to offer a more differentiated view on history and memory politics in the different countries under discussion.

In this introductory essay, we begin by discussing World War II memory in our region in light of the war in Ukraine that is ongoing at the time of writing (2017). We outline the main contours of the interplay between "memory wars" and real war, and the important "postCrimean" qualitative shift that we see in local memory cultures in this connection. Next, we sketch out a brief overview of the specifics of the war memory landscapes of the region, and then of each of the three individual countries, before moving on to introduce the book's key organizing themes and findings.

\section{From Memory Wars to Real Wars}

The post-Soviet "memory wars"- the ongoing struggle to define and narrate the past as a foundation for present and future identities-and the real war currently underway in the Donbas, are deeply 
interconnected on multiple levels. Memory politics have shaped and driven the current violence in Ukraine in important and complex ways. The ideological justification for Russian aggression against the fledgling Ukrainian state has been based heavily on claims about the memory of the past, and the current war in Ukraine is routinely imagined, narrated, and justified as a continuation of World War II. Pro-democratic forces in Ukraine have been systematically demonized in the Russian media as "neo-Nazis," intent on erasing the historical memory of the Soviet Victory and perpetrating genocide against Russian and Jewish minorities. The "fascist" label is routinely applied not just to Ukrainians, but to a diverse range of objects at home and abroad, from Russian schoolchildren researching their family histories (Pavlova 2016), ${ }^{4}$ to Western human rights activists (Obukhov 2016). ${ }^{5}$

At one level, this is nothing new. For decades now, the past has been a key battleground in the struggle for the present and future in our region. Memory activism played a prominent driving role in protest movements in the twilight days of the Soviet bloc, and ever since, symbolic politics surrounding the past have been a crucial site of contestation, reflecting and shaping post-Soviet evolution in important ways (Miller and Lipman 2012; Tismaneanu et al. 2010; Stan 2008). In particular, debates over how to commemorate victims of state violence in the past have been closely intertwined with debates over human rights in the present, as they have elsewhere in the world. (On the linkage between human rights and remembrance, see Huyssen 2003; Winter 2013.)

But with the beginning of the war in Ukraine, we can talk about a new quality of post-Soviet memory politics, or perhaps even a new phenomenon that goes beyond the usual ways of instrumentalizing the past. In the current Russian-Ukrainian conflict, we are witnessing the emergence and in some cases the cultivation of what amounts to a new temporality in which elements of past and present are fused together, and linear historical time collapses.

Some of the most striking manifestations of this dissolving of the boundaries between past and present have involved the public performance of memory. Consider the following example. In Donetsk, on Ukrainian Independence Day on 24 August 2014, Ukrainian prisoners were forced to take part in a "parade of shame," paraded in front of angry crowds of civilians who were encouraged to pelt them with rotten food and spit on them, while a street-sweeping machine followed behind the parade to cleanse the road in their wake. Importantly, this parade 
was staged and framed as a re-run of Stalin's famous 1944 "Parade of the Defeated," when German prisoners of war were marched through Moscow, followed by street-sweepers symbolically cleaning the road. It was precisely this parallel that steered the collective emotions at work here. Here, then, seven decades after the Great Patriotic War ended, a sacralized narrative of the history of that war was used by proto-fascist Russian organizations to legitimize a ritualized act of violence and humiliation staged around the public performance of memory.

The prominent role played by historical re-enactors in the current war in Ukraine offers another example of the radical blurring, even dissolving, of the boundaries between past and present, and fantasy and reality, enacted through the performance of memory. Certainly, historical re-enactments have become a global phenomenon, one of the many new forms through which contemporary societies are engaging with their past. And yet, in our region we see something new. What is elsewhere usually an innocuous hobby for amateur historians, nostalgists, and medieval enthusiasts, has gained a more sinister hue. Amateur battle reconstruction enthusiasts provided many recruits and indeed leaders for the pro-Russian separatist movement in Ukraine (see Zhurzhenko 2015a; Mitrokhin 2015: 228-229). In this way, as Alexander Etkind put it, historical reconstruction began to "swallow up the present" (cited in Zemtsov 2014), as historical play and reality became confused and interchangeable, with destructive consequences. ${ }^{6}$

Moreover, historical reconstruction has become an instrument for manipulating public memories and mass emotions, merging popular entertainment and state-sponsored political spectacle. Re-enactments of battles have been a visible feature of the lavishly funded shows staged annually in the Crimean city of Sevastopol by the Night Wolves patriotic bikers' club-a new high-profile memory actor that regularly stages flamboyant performances of memory, skillfully courting global media attention, and enjoying the patronage of the Russian president. The Night Wolves' annual shows offer abundant compelling examples of the performance and narration of memory. Their 2014 show, entitled "The Return" in honor of the Crimean annexation, featured a procession of thousands of motorbikes, organized into columns, culminating at the local World War II memorial complex, as well as the use of military hardware provided by the Black Sea Fleet (Savchenko 2014). The 2015 show, "Forge of Victory," took World War II as its theme, and in the finale, the audience re-lived the war memory, which 
was performed by present-day soldiers using genuine World War II weapons:

At midnight exactly, the lights went out, and then a German Messerschmitt appeared and bombardment commenced. And then: the Victory battles ... Real military hardware from World War II took part in the show. The tanks and "Katiushas" had shot at German soldiers 70 years earlier. Military men with combat weaponry served as extras. (Khanin 2015)

These spectacular historical re-enactments are reminiscent in some respects of the mass street theater re-enactments of the October Revolution staged to mark revolutionary anniversaries during the early Soviet period. It is often claimed that more people died during the 1927 re-enactment of the storming of the Winter Palace than during the original 1917 events; in any event, in both cases we see clearly that the re-enactment exceeds the original event, and reinvents the past for the purposes of the present. Indeed, for Russian neo-imperialist ideologue Aleksandr Prokhanov, whose "Fifth Empire" concept provided the theme for the Night Wolves show in August 2016, this show was "bringing a new reality into being" (cited Meduza 2016). ${ }^{7}$

These are just a few examples of the extraordinary ways in which recent performances of memory in connection with the war in Ukraine have aimed at endowing the past and present with meaning. Jay Winter writes that: "Memory performed is at the heart of collective memory" (Winter 2010: 11), and several of the contributors to this book explore the ways in which various commemorative rituals serve to delineate the boundaries of post-Soviet identities, and often to identify and construct "enemies." We examine the phenomenon of historical re-enactment (in Chaps. 3, 7, 8, and 14), and other new performative practices that redefine the relationship between the living, the war dead, and the unborn, such as the Immortal Regiment processions in which people march through public spaces bearing photographs of their ancestors who fought in the war (Chap. 11), or the popular fertility rituals performed by newly weds at tanks and other World War II monuments (Chaps. 8 and 15). Apart from being important contributions to memory research, these chapters advance our understanding of the mechanisms of collective mobilization in times of political crisis. More specifically, they help to find answers to one of the central questions of the Ukrainian-Russian conflict: how is it that historical myths and visions of the past projected 
onto the present can make people see the current war as an unfinished battle of World War II, even motivating some of them to take up arms?

\section{A Region of Memory? Beyond National Memories in Belarus, Russia, and Ukraine}

The emerging subdiscipline of East European Memory Studies often deals with the Western/Eastern Europe divide, with Russia bracketed out to one side as something of an exceptional case. Our focus on Russia-Ukraine-Belarus is aimed at presenting a more differentiated picture of (this part of) Eastern Europe. The current Ukraine-Russia conflict obscures the fact that there are still many continuities with the Soviet era, when these three Republics constituted the Slavic core of the Soviet Union and the memory of the Great Patriotic War shaped the essence of the late-Soviet identity. It was of course Ukraine (with the exception of its western regions), Belarus, and the western regions of Russia where the collective experience of World War II corresponded most closely with the official Soviet narrative of the Great Patriotic War; this helped to foster its acceptance by the local populations and its successful usage by the post-Soviet elites. At the same time we are now at the point where emerging national myths of World War II are dramatically diverging.

The post-war Soviet Union drew its legitimacy from the victory over Nazi Germany, and the official representations of the war were based on a triumphalist and heroic narrative of the "Great Patriotic War" that was elaborated in the Brezhnev era (Weiner 2001; Dubin 2005). This policy helped to suppress the traumatic memories not just of the war itself, but also of the unacknowledged Stalinist repressions (Etkind 2013). It also contributed to consolidating the collective identity and to shaping the supranational community of the "Soviet people" (on which see Brunstedt 2011).

The myth of the Great Patriotic War was the cultural foundation not only of the "new historical community of Soviet people" more broadly, but also more specifically of the subset of the three Slavic republics which comprised the ethnic and cultural core of the USSR. The myth of the "common victory" played a special role in relations between Moscow, Kyiv and Minsk; it corresponded to the basic historical paradigm of East Slavic unity and "brotherhood" (Yekelchyk 2004). In Ukraine, it helped to silence the counter-memory of the anti-Soviet nationalist resistance 
and its collaboration with the Nazis (cf. Grinevich 2005). In Belarus, the mythologized self-image as the "Partisan Republic" that had played a key role in defending the Soviet Union and enabling the Victory became the defining feature of the post-war polity.

While Ukraine, Russia, and Belarus shared the basic symbols and narratives associated with the Soviet myth of the Great Patriotic War, the post-Soviet histories of that myth have diverged in important ways across the three countries. While in Russia the myth of the Great Patriotic War has been integrated into the new official narratives of Russian identity, state patriotism and military glory, in Ukraine a "divided culture of memory" prevented the national elites from a consensual view on World War II. In Belarus, where the Soviet war myth has been even more important than in Russia, the traditional Soviet narrative preserved by the Lukashenka regime has been increasingly challenged by oppositional intellectuals who are practically not represented in the state-controlled public space. Meanwhile, recent years have seen ongoing struggles for "ownership" of the Victory. Most notoriously, in 2010 Putin stated that Russia would have won the war "even without Ukraine." 8 Both in Ukraine and Belarus the narrative of "common victory" and "common sacrifice" has been appropriated by the pro-Russian political forces. In post-Maidan Ukraine, a new consensus has emerged on World War II as a tragic rather than a heroic event in the nation's history, and the Great Patriotic War formula has disappeared from museums and textbooks. At the same time, references to the Great Patriotic War are not rare in the public speeches of Ukrainian President Petro Poroshenko in the context of the Russian aggression in the Donbas.

With the disintegration of the Soviet Union, Brezhnev's memory empire did not collapse at once; its fragments were instrumentalized by the political elites in the new independent states. Scholars of East European memory have tended to focus on the processes of the nationalization of memory after the end of the Cold War (see for example Müller 2002), but the instrumentalization of memory in our region does not necessarily serve the purposes of creating new national independence narratives. One example is the Prokhorovka war memorial (1995) near Belgorod which was integrated into a new narrative of Slavic unity and became a mandatory site to be jointly visited by Russian, Ukrainian and Belarusian leaders (Zhurzhenko 2015b). An Orthodox chapel with a "Bell of Unity" was erected for the meeting of Putin, Lukashenka, and Kuchma in Prokhorovka in May 2000; it is decorated with the 
icons of three saints - the patrons of the three Slavic countries. Patriarch Aleksii II, who had inaugurated the meeting of the three presidents in Prokhorovka on the occasion of the 55th anniversary of the victory over Nazi Germany, stressed the issue of Slavic unity in his speech:

Sons of the Russian, the Ukrainian and the Belarusian nations fought here heroically against the common enemy, protecting their common Motherhood. Many of them gave their lives for our peaceful and free future. Nobody can separate their graves. In fight, in sacrifice, in Victory they were together. They share military glory and we share the memory of their deeds ... Our best gift to their memory will be a strong union of the Ukrainians, the Russians and the Belarusians. ("Patriarch" 2000)

By the mid-2000s Prokhorovka became a symbol of the "East Slavic reunification," understood as the political, economic and cultural reintegration of the three former Soviet republics. Political elites interested in this project have sought to reinscribe the "Great Victory" into a new discourse of pan-Slavism and Orthodox unity, adapting Soviet symbols, narratives, and rituals to this end.

Thus, the self-defined (or, arguably, Russia-defined) East Slavic core of the former Soviet space is a paradigmatic region of memory, that is, a "discursive arena above the level of the nation-state but not fully universal" (Olick 2015: x). This memory region is both institutional and experiential: it is observable both in the mnemonic interactions of state and non-state organizations and in the shared history of wartime suffering and post-war Soviet politics. The case of Prokhorovka shows that political elites in Belarus, Russia, and Ukraine have built legal, bureaucratic, and symbolic structures to attempt to unify the narrative of the war and promote claims of shared identity. Another example is the commemoration of the "International Day of the Liberation of Nazi Concentration Camp Inmates" on 11 April, a calendar holiday unknown outside the post-Soviet states (Bekus 2016). More recently, in the aftermath of Russia's invasion of Eastern Ukraine and Crimea, such top-level commemorative cooperation has declined. For example, in 2015 Belarus enacted a symbolic rejection of Russian memory models when it introduced an alternative to the St George's Ribbon, the Flower of Victory, an apple flower on a red and green ribbon now worn by veterans and spectators during the Victory Day celebrations of 9 May. ${ }^{9}$ Nonetheless, it remains clear that memory symbols and narratives are closely intertwined 
in this region: the sharing of tropes has increasingly given way to memory conflict, but the connectivities of memory remain strong.

This regional perspective is a fruitful prism for studying the memory cultures of Belarus, Russia, and Ukraine because it recognizes that the specific Soviet myth of the Great Patriotic War was hugely formative for these three countries, whilst also allowing for the dynamic study of how memory regimes have evolved and influenced each other across national borders. Thus, our decision to focus on the Russia-Ukraine-Belarus triangle should not be read as indicating a tacit acceptance of the ideological construct of primordial East Slavic unity and brotherhood. ${ }^{10}$ The essays in this volume overwhelmingly show that memory is contested both within and between states.

The trajectories of memory in these former Soviet countries also provide an instructive counter-example to the popular argument that the Holocaust has become a global symbol of twentieth-century suffering (Levy and Sznaider 2002). Somewhat paradoxically, in the very lands where the mass killing of Europe's Jewish population was unleashed on an industrial scale (alongside Poland, Hungary, the Baltic States, and other East European states), the metanarrative of the Holocaust's centrality to global memory culture is debunked. The Holocaust is certainly not forgotten here, despite the fact that the official Soviet narrative allowed no concessions to the specific suffering of Jews, instead generalizing about the deaths of "peaceful Soviet citizens" (see Al'tman 2005). However, the Holocaust is decidedly not a principal pillar of memory in the region; rather, it competes for supremacy with other foundation myths, including the cult of Victory and national martyrologies (see Chap. 12).

Meanwhile, the memory of the Holocaust can be seen as a site of negotiation between the local and global. Political elites, regardless of their views, cannot avoid references to the Holocaust as a universal symbol of twentieth-century history. The global discourses of Holocaust remembrance and human rights have been appropriated and adapted in various ways by the Putin regime as a self-legitimizing move (see Fedor 2015: 2), while Ukraine's pro-Western government addresses the issue of Holocaust in order to demonstrate its commitment to European values. At the same time, the unprecedented public commemoration of the 75th anniversary of Babiy Yar in Kyiv in September 2016 and new memorials created by the efforts of civil society (such as the Space of Synagogues in Lviv) testify to a new trend towards integrating the Holocaust into the national historical narrative. 
Overall, all three memory cultures remain fundamentally structured by the Soviet Great Patriotic War myth. This applies even when and indeed especially when their positions on that myth are starkly opposed to one another. As Michael Rothberg has argued, the virulence of conflicts over memory is in part a result of "the rhetorical and cultural intimacy of seemingly opposed traditions of remembrance" (Rothberg 2009: 7; original emphasis). Rothberg's observation that our relationship to the past always has "unexpected or even unwanted consequences that bind us to those whom we consider other" (Ibid.: 5) is particularly apt here, where seemingly radical attempts to reject the Soviet paradigm so often only serve to entrench it further (see Portnov 2016). Bitter debates on the role of Stalin in Russian history, and in particular, his role in the victory over Nazi Germany, which paradoxically unite liberals and nationalists in one discursive realm, prove this point (cf. Chap. 2). As Yuliya Yurchuk shows in Chap. 4, attempts to create an anti-Soviet nationalist narrative glorifying the Organization of Ukrainian Nationalists (OUN) and the Ukrainian Insurgent Army (UPA) as national heroes often copy the traditional Soviet narrative and borrow from its stylistic repertoire. The same can be said of some nationalist narratives in Belarus (see Chap. 13), where, at the same time, the ruling regime is increasingly borrowing from the opposition's depository of symbols and narratives (cf. Chap. 3).

Mark D. Steinberg suggests another perspective on Eastern Europe that is useful for framing our approach here. He writes:

if we hold to the definition of region as a space constituted by social relationships rather than by commonalities of culture, eastern Europe is very much such a relational space, with its distinctive legacies of enormous diversity and often sudden change, and especially of forceful modern attempts to unify and stabilize relationships by absorbing difference into empires and multinational states or attempting to eradicate difference. (Steinberg 2014: 75-76)

In the case of our three countries, it is relevant to mention that their relations have often been imagined and structured by kinship narratives and metaphors linked to kinship, rather than, say, to "neighborly" relations or "partnerships." Recognition of this is crucial for understanding the emotional dimension to the memory wars. It is frequently asserted in the Russian press, for example, that what makes the post-Soviet 
memory wars "especially hurtful and bitter," as one journalist put it, is the fact that "kindred [rodstvennye] Slavic peoples are included in the circle of main enemies" (cited in Maevskaia 2009). The old metaphors of Slavic brotherhood and Slavic blood ties thus continue to exert symbolic power, but now often carry a negative charge. Whilst insisting on shared collective kinship among the peoples of the USSR, Soviet propaganda also denounced Ukrainian nationalists during World War II as "betrayers of the Motherland" (cf. Chap. 4), and this accusation echoes in the recent memory wars in post-Soviet space. A new monument to the "victims of the OUN and UPA" erected in Simferopol in Crimea in 2007 under the title "Shot in the Back" represents a wounded Soviet soldier embraced and supported by a woman. The history of this metaphor goes back to the imperial period of Ukrainian-Russian relations (Kappeler 1997). This fact helps to explain the emotional power of the notion of "treachery" in the context of the current Ukrainian-Russian conflict as pro-Western Ukraine is presented as a Trojan horse of US imperialism. Thus, the dominant trope of "fraternity" has now effectively been turned inside out, and transformed into the new key organizing metaphor of "betrayal". The persistence of this underlying idea serves to radically limit the available role categories to a stark choice: brother or traitor.

In post-Soviet space, successful instrumentalization of war memory has been enabled by the fact that, at the level of popular attitudes, the myth of the Great Patriotic War has remained even more important than at the level of elite politics. Frederick Corney has observed that: "Successful foundation narratives are commissioned in a complex relationship between rulers and the ruled", and that their viability "depends on their ability to draw individuals into the process of meaning-making" (Corney 2004: 2-3). Victory Day (9 May) marking the end of the war is the most important commemorative date on the Russian official calendar; it also happens to be the only post-Soviet holiday that is genuinely popular in Russia (Levinson 2015) and beyond its borders (Gabowitsch et al. 2016). As Nina Tumarkin puts it, during the late-Soviet period, Victory Day "was both the tool of propagandists touting its triumphs and a memorial day for millions of relatives and friends of the war dead" (1994: 37; original emphasis). The powerful emotional connections between the levels of individual/family and collective memories of the war mean that the Great Patriotic War myth continues to fulfill the criteria set out by Stephen Kotkin in his study of Soviet ideology and 
propaganda. Kotkin points out that it is not possible simply to impose propaganda from above. In order to be effective, Kotkin writes, propaganda "must offer a story that people are prepared at some level to accept; one that retains the capacity to capture their imagination, and one that they can learn to express in their own words" (1995: 358). The war myth continues to succeed in doing all these things. Seen retrospectively, after Crimea, it still represents the strongest identity marker of the "Russian world," broadly understood as the East Slavic, or Orthodox civilization. As the "Russian spring" of 2014 demonstrated, even a quarter of a century after the collapse of the Soviet Union, cultural and ideological attachment to the myth of the Great Patriotic War overshadows political loyalties to the new nation-states.

\section{RUSSIA}

It has become commonplace to point out that the Soviet Victory is now the single most important historical event capable of acting as a foundation stone for a post-Soviet-Russian national identity (see for example Gudkov 2005; Wolfe 2006). In important ways, the Victory has come to displace or stand in for other candidates for the role of a symbol of national unity through shared suffering and victimhood, such as the Gulag. The Russian Federation's position as semi-successor state to the USSR rules out the possibility of externalizing the history of Soviet state violence. Instead, as Serguei Oushakine has argued, the war memory seems to function as a kind of placeholder, a "black hole" into which all of Russia's unacknowledged twentieth-century traumas can be absorbed (cited in Kosterina 2015).

Despite the breaking of various taboos around the Soviet role in the war in recent decades (on which see Carleton 2016), the Soviet myth of the Great Patriotic War, now reconstituted and integrated into a new narrative of Russian history, largely retains its status as sacred and untouchable. Successive governments have put significant resources into fostering the use of the Victory cult as an instrument of national consolidation and patriotic education. The Victory myth has been deemed so crucial to the nation-building project that it requires direct government intervention: for example, denial of the Red Army's Victory has been made a criminal offence.

The Soviet role in defeating fascism is also an important element underpinning Russian geopolitical claims to great power status (see 
further Zhurzhenko 2015a). The current Russian government has also made wide use of the symbolic capital derived from this in its relations with the former Soviet countries by labeling any moves to depart from the Soviet narrative of the war (or by extension from the Russian sphere of influence) as "fascist." Since 2014, tropes and images from the Soviet myth of the war have also been "weaponized" to incite pro-Russian insurgency in Ukraine. For example, the tragic events in Odessa on 2 May 2014, when clashes between the Euromaidan and the Anti-Maidan ended with a catastrophic fire in the Trade Union house which took the lives of dozens of pro-Russian protesters, was widely labeled "a new 'Khatyn'," that is, a repeat of the massacre of civilians that took place in the Belarusian village of Khatyn' in 1943 and which later became an emblematic "fascist" crime in the Soviet war narrative. The victims of the 2014 Odessan fire were in turn claimed as martyrs to the cause of building "Novorossiia" in Ukraine (see for example Darenskii 2015). The victims were said to have died to enable the beginning of the "Russian Spring," on the one hand, and in the name of past Russian military victories, on the other, and these two dimensions were often closely intertwined. One Orthodox priest commenting on these events, for example, described the Odessan fire as "A BURNT OFFERING ... an auspicious sacrifice ... and an eternal cursing of the Nazis!" [original emphasiseds.] (cited in Chistiakov 2014: 3). This is only one example of how the memories of World War II have been mobilized to incite the antiUkrainian insurgency by equating Ukrainian nationalism with German Nazism as the embodiment of absolute evil.

Thus, seventy years after the victory over Nazi Germany, Russia claims to be facing the same challenge-the threat of fascism. "Anti-fascism" has thus become a central element of the new national idea and the motor of mass nationalist mobilization in today's Russia. ${ }^{11}$ This new politics of memory is pervasive: it stretches from official discourse and diplomatic rhetoric to mass media, cultural production (films, plays, even operas) and academic history writing.

The Ukrainian events coincided with a wave of memory wars within Russia itself. In the first half of 2014, Putin signed into law the criminalization of "the dissemination of knowingly false information about the actions of the USSR during World War II" (Sova 2014); a former state security official was appointed head of Moscow State University's Contemporary History Department (Aptekar' 2014); and the historian Andrei Zubov was sacked (albeit temporarily) from his university post 
over an article in which he compared current policies on ethnic Russians in the near abroad to the Nazi handling of the Sudeten Germans issue (Antonova 2014) - to give just a few examples. As this book's manuscript was finalized, in August 2016, we saw the first case of a criminal conviction being brought down (and upheld by the Supreme Court) under the abovementioned 2014 addition to the Russian Criminal Code, article 354.1 , on the "Rehabilitation of Nazism." 12

Commentary on Russian memory politics often focuses on the issue of continuity between the Soviet Union and the Russian Federation, the prospect of a Russian-led attempt to recreate the Soviet Union, and the advent of a "new Cold War." We view such notions as something of a red herring, and one that is moreover convenient in various ways for the current Russian regime, whose leaders frequently present themselves as the only alternative to a full regression back into Stalinist habits and practices and ancient tendencies arising inevitably out of the Russian national character. It is in the Putin regime's interests to use politics around the past in order to distract people away from political choices in the present. Again, this has less in common with the Soviet use of the war myth than it might seem. In contrast to the old Soviet ideology, which represented a coherent and stable system, Putinist ideology is heterogeneous and eclectic, selecting and combining elements of both the Soviet and imperial narratives with the aim of demonstrating Russia's "greatness."

It is important to bear in mind that, far from representing an inevitable resurgence of old grievances and "ancient hatreds," the memory politics currently being conducted are very much a matter of active and deliberate myth making on the part of contemporary elites. Duncan S.A. Bell highlights the fact that myths "do not simply evolve unguided, without active agency ... Myths are constructed, they are shaped, whether by deliberate manipulation and intentional action, or perhaps through the particular resonance of works of literature and art" (Bell 2003: 75). We might view what is happening in Russia not as a climax of cultural and political conservatism but rather as the invention of a new nation, as the Russian oppositional journalist Oleg Kashin suggested in a polemical column on contemporary Russian memory politics on the occasion of Victory Day 2016. In his article, entitled "A New Holiday for a New People," Kashin noted that while Russians were used to thinking of themselves as an old narod with a rich culture and history, it made sense in fact to think of Russians as: 
a new narod, a narod that is in the process of being created artificially right now at an accelerated tempo, like the Turks under Kemal. A narod like this needs precisely a myth like this - a myth of ancestors who smashed the threat from the West in a bloody war, who were loyal to their state and prepared to sacrifice themselves for the sake of its interests. (Kashin 2016)

In this sense, Russia is in fact not so different from Ukraine and Belarus, which are more often and more readily seen as "new" nations in urgent need of their own history and identity.

\section{UKRAINE}

Unlike in Russia, in Ukraine conflicting views on the Soviet past and alternative interpretations of World War II have contributed to a profound political conflict which splits the society. In this respect Ukraine resembles a country that experienced civil war, such as Spain (Shevel 2011). The right to interpret the historical and geopolitical outcome of World War II has been openly claimed by competing political forces. The reinterpretation of World War II and its role in Ukrainian history is directly linked to the "post-colonial" search for national identity and the problem of geopolitical choice between Russia and the West. While during Leonid Kuchma's decade (1994-2005) officials referred to World War II as the "Great Patriotic War of the Ukrainian people," thereby endowing the Soviet narrative with national meaning, in the official discourse of the Yushchenko era (2005-2010) the Ukrainian nation figured as a victim of two totalitarian regimes. According to Sofia Grachova (2008: 4), "the new official historical narrative represented the war not so much as a glorious event, but rather as a terrible tragedy that struck the Ukrainian people in the absence of a national state." During the Yanukovych era, this approach was marginalized, and some of the old Soviet symbols (such as the Soviet flag in the form of the Banner of Victory) were officially reintroduced, provoking severe conflicts.

In Ukraine, unlike in Russia and much more so than in Belarus, a nationalist counter-narrative to the Great Patriotic War has existed since the late 1980s, referring to the OUN-UPA and its leaders, Stepan Bandera and Roman Shukhevych. This narrative, rather marginal during the first post-independence decade, was elevated to the level of national memory politics in the era of Viktor Yushchenko. His symbolic politics, which aimed at the glorification of Ukrainian nationalism and 
at denouncing the Soviet regime as anti-Ukrainian, polarized the country. The Eastern Ukrainian regions being the stronghold of the Party of Regions became the main arena of memory wars during Yushchenko's presidency.

As some commentators have pointed out, these memory wars prepared the ground for the armed conflict in the Donbas: "the war in Eastern Ukraine (called an anti-terrorist operation) officially started in April 2014. The war in peoples' minds, which now seems to be an integral (and natural) part of the current military and civic conflict started much earlier-when the past became an important element of the present" (Kasianov 2014). Addressing the role of identity politics in the current Ukrainian crisis, Zhurzhenko (2014) has shown how Ukraine's divided political elite opened the Pandora's box of memory politics, using it as a tool for mass electoral mobilization, and how Russia has profited from the "war of identities" in its efforts to weaken Ukraine and prevent its reorientation to the West.

Andrii Portnov has offered one of the most balanced and measured accounts of the revival of the Bandera mythology in the course of the Euromaidan protests. He notes that in addition to the far-right adherents of the Bandera myth, there were also those who took up this myth in a gesture of reappropriation in response to the Kremlin's campaign to represent the Maidan as "fascist," and often in ignorance of Bandera's biography and views (2016). Others too have drawn attention to the ways in which Bandera as a symbol acquired new meanings in the course of the Maidan protests, at least partly becoming decoupled from Bandera's legacy of exclusivist ethno-nationalism (see Kulyk 2014; Yekelchyk 2015). Ultimately, as Portnov argues, "many people were trapped by the same propaganda narrative they wished to oppose" (2016).

Among the most divisive recent developments in the Ukrainian politics of war memory has been the renewed "decommunization" process currently underway. This process must be viewed in the context of the present war with Russia and Russia-backed separatists. This war has, understandably, strengthened the narrative of national liberation struggle officially propagated by the Institute for National Remembrance, led by the controversial historian Volodymyr Viatrovych. Viatrovych, who downplays crimes committed by the Ukrainian nationalists against Jews and Poles during World War II, has long been a target of domestic and international criticism (see letter of Western historians Marples 2015; Miller 2016). In 2015, four laws on new memory politics in Ukraine 
drafted by the Institute were adopted by the Ukrainian Parliament on 9 April and later signed by President Poroshenko on 15 May, despite international and domestic criticism and pleas to bring them in line with European human rights legislation (Marples 2015).

Most of this criticism was directed against two of the four "decommunization" laws (cf. Chap. 4). The first of these is aimed at regulating representations of the controversial UPA and OUN. This law effectively creates an official canon of "national heroes," thus limiting critical public debate and complicating academic research on these issues. The second law officially condemns the Soviet regime alongside the Nazi regime, both of which are labeled totalitarian, and criminalizes the public use of communist and Soviet symbols. Both laws have been widely criticized as an assault on freedom of speech and as imposing a narrow view of the Soviet period of Ukrainian history as occupation.

The other two laws have attracted less attention but also represent important developments in Ukrainian memory politics. First, free access was granted to the former KGB archives. Second, a significant change was made to the Ukrainian official commemorative calendar: 8 May was now designated the Day of Memory and Reconciliation. This day now coexists alongside the old Soviet Victory Day public holiday on 9 May, which remains in place. In this way, the law partially broke with the (post-)Soviet tradition of Victory Day and with the still persisting narrative of the Great Patriotic War. Ukraine has distanced itself from the Russian symbols of the Great Patriotic War (such as the St George's Ribbon) which had been used rather as a neutral symbol in the postSoviet countries prior to 2014 but became a symbol of pro-Russian separatism after the "Russian Spring." A new national symbol has been developed by the Institute for National Remembrance-a poppy flower combined with the slogan "Never Again" (Nikoly znovu) which clearly refers to the European tradition of war remembrance and its current post-heroic focus on mourning the victims of war. In the official political rhetoric and symbolic politics of the Ukrainian government, the Great Patriotic War does still play a role, however. For example, President Poroshenko makes frequent reference to the war, drawing parallels with the Russian aggression in the East, and official posters advertising service in the Ukrainian military stress continuity with the generation of Soviet veterans. One can argue that new victims, heroes, and martyrs of the war in the Donbas relativize the memory of World War II, although its highly politicized symbols such as the St George's Ribbon 
still polarize society, and clashes between the pro-Russian opposition and Ukrainian radical nationalists have become typical for the 9 May public commemorations.

Alternative nation-building projects are underway in the so-called "Donetsk People's Republic" (DNR) and the "Luhansk People's Republic" (LNR) with their own collective mythologies, heroes, and martyrs, and even a new national mission, waged under the banner of "anti-fascism." The myth of the Great Patriotic War serves as glue holding together heterogeneous symbols, such as the Russian Cossackry, the figure of the heroic working-class miner, and the Orthodox Church. In the rhetoric of the self-proclaimed leaders of the DNR and LNR, the survival of the "young republics" is celebrated as "victory" reminiscent of the Great Victory of 1945.

\section{BELARUS}

Belarus is similar to Ukraine in the polarization of memory between pro- and anti-Soviet models, but also very different in that the antiSoviet mythology of the war is marginalized from public discourse and is unlikely to enter a position of power in the foreseeable future. The two-decade-old regime of Aliaksandr Lukashenka has from the outset gained its political legitimacy from recycling the Soviet myths of "fraternity" with Russia and collective heroism during World War II. National consciousness had been comparatively weak in Belarus when the Soviet project began, and in seventy years of communist rule, the Moscow-led authorities were rarely compelled to make concessions to Belarusian national aspirations. Thus, the central post-war myth of the "partisan republic" was largely successful in cultivating Soviet loyalty: in March 1991, 82.7 percent of Belarusians supported the preservation of the USSR (Marples 2003: 21). In summer 1994, Lukashenka, previously an unknown figure in Belarusian politics, tapped widespread social anxiety, economic uncertainty and Soviet nostalgia to gain a resounding electoral victory and become the country's first (and to this day [2017] only) president.

The memory politics of the so-called "last dictatorship in Europe" have involved a simultaneous narrowing and expansion of the cult of Victory: the semantic scope of the narrative has narrowed, but the symbolic arsenal of memory has been reinforced. If the Soviet myth of the "partisan republic" emphasized the Belarusian nation's contribution to 
pan-Soviet glory, the version promoted by the Lukashenka regime has nationalized the myth in subtle but perceptible ways: the nation is now presented as the main actor and beneficiary of the heroic wartime resistance (Rudling 2008; Marples 2014). The Flower of Victory can be seen as the latest incarnation of this isolationist memorialization. Whilst in 2015 the Ukrainian authorities adopted the overtly Western symbol of the poppy and thereby sought to transplant the country from the Eurasian to the European civilizational model, Belarus chose an apple flower adorned with the colors of the national flag (Red and Green). The Lukashenka regime opted for a new, semantically empty symbol that both rejects the Russian memorial hegemony of the St George's Ribbon and maintains a distance from the Western European victim-centered narrative. The Belarusian case is therefore a curious patchwork of reworked Soviet tropes that simultaneously assert Eurasian civilizational identity-rejecting Western victim-centered narratives and claiming descent from the pan-Soviet Victory-and carve out a separate, nonRussian space of national memory.

To help promote this vision of Belarus's historical and mnemonic Sonderweg, the state has carried out costly refurbishments of Soviet-era monuments, such as the Khatyn Memorial Complex (opened 1969, renovated 2006; for further discussion see Rudling 2012 and Lewis 2015), and it has also added new sites of memory, such as the Stalin Line museum (opened 2005, discussed in Chap. 8; Marples 2012). July 2014 saw the grand reopening of the Museum of the Great Patriotic War in Minsk: this major Soviet-era institution was relocated to a new, purpose-built building and revamped with a significantly enlarged exhibition space, interactive expositions, and a highly charged social and political purpose. The opening ceremony was attended by both Lukashenka and Putin, a fact that bears witness to the museum's transnational political significance. This costly and widely publicized project allows visitors to imagine themselves in reconstructed war scenes, combining a sanitized narrative of Belarusian-Soviet military victory with enjoyable, 3D performative affect (see Bratachkin 2015; Lastovskii et al. 2014). As a museum that modernizes the (official) memory of the war for generations that have no lived experience of this history, it leaves no doubt as to the continued centrality of the Great Patriotic War to the identity project of the Belarusian authorities.

Yet at the same time, the Lukashenka regime has gradually diversified its approach to war memory. The myth of the partisan republic is 
still paramount, but it is no longer a monolith. As both Ackermann and Rudling show in their chapters, complex forms of interaction between state and grassroots activists have led to the official sanctification of previously unheralded narratives, from the Soviet war in Afghanistan to the Battle of Orsha, fought between the armies of Poland-Lithuania and Muscovy in 1514. The Holocaust and Jewish heritage are also being incorporated into the accepted symbols of official commemoration, as demonstrated by Lukashenka's participation in a 2014 memorial ceremony at the site of Trastianets, a former Nazi killing field where more than 200,000 individuals, mostly Jews, were murdered during the war (Waligórska 2016). Needless to say, the increasing number of memory symbols does not correspond to a change in the dominant memory regime: the mode of remembrance remains resolutely triumphant, framed in terms of heroism and martyrdom rather than victimhood and mourning.

This heterogeneous instrumentalization of memory and the general popularity of the Victory myth make it difficult for the political opposition to dispute the state's central claims about the war. If in Ukraine, the wartime anti-Soviet (as well as anti-Polish and anti-Semitic) actions of the Bandera and Shukhevych militias are readily advanced as a counter-narrative to the Soviet interpretation of military victory, in Belarus the wartime nationalist-collaborationist movement does not easily lend itself to such lionization: it was comparatively weak and thoroughly discredited during the post-war decades. There have been attempts to raise historical figures such as Usevalad Rodz'ka, a potential Belarusian "equivalent" of Bandera, to the status of a national hero, but these have so far failed to gain traction (see Chaps. 3 and 13). Instead, the most prominent attempts to decouple Belarusian identity from Soviet metanarratives tend to focus on the crimes of Stalinism, considered independently of the war. The best known and politically "hottest" site of anti-Soviet memory is the Kurapaty Forest, a mass burial site for victims of NKVD executions during the Terror of the late 1930s (Marples 1994; Etkind et al. 2012). Nonetheless, as Chap. 13 discusses in more detail, the process of unmaking the myth of the partisan republic has unfolded in literature and culture, and continues to this day.

Given Belarus's self-imposed relative isolation from Eastern European memory wars and its uneasy neutrality in the ongoing Russia-Ukraine conflict, it is not surprising that the mnemonic dimension of the war in Eastern Ukraine has had comparatively few effects on war memory 
in Belarus. There has been no need for the Kremlin to rebrand a section of Belarusians as "fascists," and official Minsk has not been moved to designate a new day on which to mark Victory Day in order to snub Moscow. Instead, Belarus has quietly distanced itself from the Russian memory frame, for example in Lukashenka's decision not to attend the 9 May celebrations in Moscow in 2015. Against the background of events in Ukraine, Lukashenka's snub and the Flower of Victory are minor changes that suggest an apprehensiveness against Russian influence, but hardly a desire to antagonize. Regional politics may yet have a profound effect on Belarusian war memory, but for now the memory war is mostly confined within the boundaries of the state.

\section{OUtLINE OF THE BOOK}

The volume is divided into five parts, each comprising three chapters.

Part I: Memories of World War II and Nation Building begins at the national level with an introduction to each of our three national cases. With the dissolution of the USSR in 1991, Ukraine, Russia, and Belarus embarked on a difficult process of building new states and consolidating their populations as national communities. While the myth of the October Revolution and the Soviet ideology was relatively easy to give up, the so-called "Great Patriotic War" was deeply rooted in collective memory, mass culture, and public discourse. Post-Soviet political elites, which in all three countries largely originated from the Soviet nomenklatura, have been seeking a difficult balance. On the one hand, new national symbols and narratives referring to the pre-Soviet era were initially met with skepticism by significant parts of the population; on the other, the Soviet myth of the Great Patriotic War served as a familiar and comforting symbol of continuity in the uncertain times of transition. The state has traditionally played an especially prominent role in memory politics in all three post-Soviet countries, and so these chapters share a particular focus on official memory politics and the role of political actors and institutions such as president and parliament in shaping their agenda. This section addresses similarities and specificities of the three national cases, helping to set the scene for the remaining chapters.

Olga Malinova begins with a survey of post-Soviet-Russian memory politics on the war, tracing the evolution of official attempts to use the war memory for identity-building purposes through from the early 
1990s to the present day. She tracks these changes through a detailed frame analysis of presidential speeches and commemorative ceremonies.

Next, Per Anders Rudling guides us through both the official and the oppositional use of historical myths and narratives. Like Malinova's chapter, Rudling's highlights the ways in which the state authorities have sought sources of legitimacy in the past, taking over and adapting Soviet and other narratives for nation-building purposes. Rudling also shows that alternative historical cultures are also present in Belarus, for example in the form of online videos and cartoons presenting nationalist narratives of Belarusian history in pop culture form. Both these first two chapters conclude that the Soviet cult of the war remains a key identity marker, in part because of the limited success that governments and elites have had in finding suitable alternatives.

Finally in Part I, Yuliya Yurchuk traces the history of successive attempts to challenge the Soviet master narrative of the Great Patriotic War in Ukraine from 1991 through to 2016. She focuses on the nationalist narrative of the OUN and UPA as fighters for Ukraine's independence during World War II, and demonstrates the impressive career of this narrative from a local "counter-memory" rooted in some regions of Western Ukraine to a new national myth legitimized by the Ukrainian state. Her account takes us through to the post-Euromaidan period, which has resulted in a bid to monopolize official memory by the Ukrainian Institute of National Remembrance.

The essays comprising Part II: In Stalin's Shadow explore the figure of Joseph Stalin and the paradox of his growing popularity in the post-Soviet era. His role in World War II remains the single most divisive aspect of the Victory cult in Russia. More than any other historical personage or symbol, Stalin-the commander-in-chief who presided over the Red Army's Victory, and the architect of mass atrocities against his own and other peoples-embodies the inseparability of the triumphalist and traumatic elements of Soviet history, as well as the ambiguities and tensions at the core of (post-)Soviet war memory. Joseph Stalin is far more than just a Russian lieu de mémoire-for example, Stalin as a symbol of the Great Victory has been smuggled into the public sphere in Belarus where his figure contributes to legitimizing Lukashenka's authoritarian regime (cf. Chaps. 3 and 8). The three chapters in Part II deal with the post-Soviet afterlife of Stalin's cult in Russia and in Ukraine. 
Markku Kangaspuro and Jussi Lassila begin with a study of the symbolic politics around the renaming of Stalingrad/Volgograd. They use this case to demonstrate the difficulties faced by various actors in Russian politics and society in handling the relationship between the closely interconnected triumphalist and traumatic associations linked to the figure of Stalin. They provide a detailed analysis of the Putin-era debates over whether the name "Stalingrad" should be reinstated. Their account highlights the limits of the Russian state's power to impose hegemonic control over narratives of the national past, and links this to the "hybrid" nature of state memory politics in Russia, combining both authoritarian and democratic features.

Serhii Plokhy's chapter examines the role that the cult of Stalin plays in articulating conflicting approaches to the history of the war in Ukraine, through a close reading of a 2010 incident in which Ukrainian nationalists ritually beheaded a statue of Stalin that had been erected by the local Communists in the city of Zaporizhzhia earlier that year. This case study demonstrates how the Soviet war myth functions as a force for division in Ukrainian society. It also sheds retrospective light on later developments in Eastern Ukraine known as the "Russian Spring," as well as helping to illuminate the driving forces behind the current Ukrainian "decommunization" campaign.

Finally in Part II, Philipp Chapkovski's chapter investigates the phenomenal popularity of neo-Stalinist literature in Russia. He views this partly as an outcome of the state's reliance on the Victory myth, which makes an unequivocal renunciation of Stalin impossible. Chapkovski sets out to discover who is writing and consuming this literature, and why. His chapter provides an introduction to the key themes and features of this genre, and places its emergence in the broader context of the historical development of neo-Stalinism in the late-Soviet period. He also compares neo-Stalinist literature to Holocaust denial literature, finding both commonalities and important differences. Moreover, he tracks the fates of the leading neo-Stalinist authors in the post-Crimean period, finding that some of them swapped their pens for guns and went to fight in the Donbas; others still have fallen from grace and now face charges of extremism, while the general trend is towards the emergence of a new "right-wing" version of Stalinism in the new political context. ${ }^{13}$

One of this book's contributions to memory studies concerns the proliferation of new groups, agents, narratives and symbols, reflecting 
the volatility, fluidity, and heterogeneity of the memory landscapes in the region. The essays in Part III: New Agents and Communities of Memory identify and discuss a selection of new memory actors and communities. We approach memory politics in post-Soviet transitional societies not only as a matter of a top-down policy of nation building and state-led identity construction, but also as a bottom-up process in which new groups, communities of memory, and commemorative agents enter public politics claiming recognition of their particular narratives, and sometimes even representation of their group interests in politics and various forms of compensation. In post-Soviet societies, these grassroots initiatives can be captured, or partially captured, by the state (see Chap. 11). At the same time, pluralization has set certain limits on the state's capacity to impose a single narrative of the past (see Chap. 5). In fact, it would be misleading to draw neat divisions between these topdown and bottom-up processes. As several of the chapters show, private, state, and social processes of remembering are deeply intertwined. In this sense our volume responds to Mischa Gabowitsch's call for post-Soviet memory studies to move beyond the binaries that have tended to structure the field to date (Gabowitsch 2015).

The chapters in Part III address three different communities of memory constituted in the post-Soviet decades: the Soviet Afghan War veterans in Belarus (Chap. 8); the "children of war" in Russia (Chap. 9); and former Ostarbeiters (forced labor workers) in Ukraine (Chap. 10). All three communities of memory are essentially transnational-associations of Afghan war veterans, "children of war," and former forced labor workers exist in Ukraine, Russia, and Belarus alike. However, we can also observe significant differences in their political strategies and forms of interaction with the state, depending on the specificities of the political regimes and nation-building processes in these three countries.

Felix Ackermann approaches the role of the Afghan war veterans in renegotiating Belarusian war memory from a special angle, via a study of two post-Soviet war memorials erected on the veterans' initiative and connecting the memories of the two wars. While the Island of Tears memorial created in the mid-1990s in central Minsk reframed the recent Soviet past as national trauma and introduced Christian symbolic language into urban space, the "Stalin Line" memorial, opened on the western outskirts of the city ten years later, reintroduced the figure of Stalin and the narrative of the Great Victory, claiming such values as patriotism and heroism for the public education of Belarusian citizens. 
The two memorials illustrate the evolution of the national commemorative culture in line with the Belarusian political regime's sliding towards authoritarianism, and the virtual continuity between the Great Victory of 1945 and the Soviet war in Afghanistan.

Tatiana Zhurzhenko's chapter explores another community of memory which constitutes itself in terms of a generation: the "children of war" in Russia. While the last Soviet war veterans are passing away, those who experienced World War II as children and adolescents now feature as the only living bearers of the memory of this epochal event. At the same time, the "children of war" generation is the most truly Soviet generation as far as their mentality is concerned. Moreover, having entered their "twilight years" in the new capitalist Russia they represent the troubled link between Soviet and post-Soviet history in a society where traditional values of respect for the elderly are in decay. By bringing together issues of generational memory, social justice and Russia's welfare state, the chapter analyzes grassroots social initiatives and strategies of the political elites in Russia aimed at the institutionalization of a special status for the "children of war."

Finally in Part III, Gelinada Grinchenko recounts the history of the emergence of another "community of memory," this time in Ukraine: the Ostarbeiters or "Eastern workers," civilians mobilized for labor purposes in the Third Reich during the war. She shows how the stories of the Ostarbeiters, which were largely silenced during the Soviet period for their dissonance with the Soviet war myth, were recovered with the arrival of Ukrainian state independence in 1991 and incorporated into new national narratives of Ukrainian victimhood. In a parallel move, Grinchenko demonstrates how Ostarbeiters as a social group were reconstituted through post-Cold War restitution politics when the German government finally acknowledged moral responsibility for forced labor as a crime of the Nazi regime and started issuing moral compensation for its victims.

Part IV: Old/New Narratives and Myths focuses on two elements that are fundamental to the creation of meaning: the narratives that shape identities, and the myths spun around these narratives. In this section, we explore different incarnations of narratives and myths of the war, past, present, and emerging, and trace their development over time.

Julie Fedor's chapter examines new Russian authoritarian kinship narratives in which the Red Army soldier is reframed as a mythical progenitor and a shared forefather for all the peoples of post-Soviet space. 
This reframing is used to connect the official cult of the Great Victory and private family memories of loss and suffering, and also to construct the "Russian world" as a space that is saturated and sanctified by the Red Army's blood.

Andrii Portnov reflects on the rivalry and interplay between two prominent narratives of the war in Ukraine: the (post-)Soviet and the nationalist narratives. While these narratives are in most respects diametrically opposed, they resemble each other in one particular aspect: both of them marginalize the memory of the Holocaust and the tragic fate of the Jewish population in Ukraine. Portnov's chapter, which traces developments from the early 1990s through to the present, can serve as an introduction for all those interested in the issue of the Holocaust in Ukraine. It offers a survey of public narratives at various levels, from the official political discourse and school history books to museums and memorials. The author shows not only where Jewish and Ukrainian narratives of World War II clash, but also where reconciliation is possible.

Simon Lewis's chapter brings together trauma theory and post-colonial theory in his study of the Soviet myth of Belarus as the "Partisan Republic," which he reads as both displaced trauma and colonial discourse. He explores a diverse range of Soviet and post-Soviet Belarusian narratives of the war in fiction, film, art, and popular culture. He shows that post-Soviet cultural production in Belarus consists of diverse narratives of Belarusian partisanhood that compete with each other to rewrite the Soviet narrative, as well as with the Lukashenka regime's resurrection of Soviet myths about the war.

Finally, Part V: Local Cases zooms in on three examples that bring together the local, national, and transnational dimensions: Sevastopol, Narva, and Karelia.

Ewa Ochman's work (2009) has highlighted the special potential that commemorative practices have at the local level when it comes to challenging top-down nationalizing narratives of the past. In addition, they can also serve as a laboratory for new grassroots initiatives which later become appropriated at the national level (as Chap. 11 on the Immortal Regiment initiative born in Tomsk also shows). The three chapters in this section explore the complex interactions between top-down memory projects, both national and supranational, and local memory actors. Adding to the complexity of multi-scalar memory politics, all three cases share a border location. Even if not openly contested by neighboring states as is Sevastopol, both Estonian Narva and Karelia bordering 
with Finland are marginal geographic locations where the core of the new Russian identity has been renegotiated in contestation with various "others."

Judy Brown's chapter explores the war mythologies linked to the city of Sevastopol, and the ways that these have been used in the disputes over the city's ownership in the post-Soviet period. Based on the author's fieldwork in the city, the chapter shows how the city's local commemorative infrastructure, relying on grassroots enthusiasm, has served to promote a Russian imperial identity for Sevastopol's inhabitants, drawing heavily on the Soviet myth of the "hero-city." A snapshot of the city indulged in neurotic obsession with its "glorious past" just a couple of years before the Russian annexation helps us to better understand the dramatic events of 2014.

Elena Nikiforova presents another urban memoryscape: that of Narva, which lies on the border dividing Russia and the European Union (Estonia), and the Russian and Estonian national memory cultures. While Narva is part of Estonia and thus in geographic terms falls outside our region, we have included this chapter because it deals with the Russian war memory which overlaps national and even geopolitical borders, as this chapter emphatically shows.

Finally, Aleksandr Antoshchenko, Valentina V. Volokhova, and Irina S. Shtykova explore the distinctive memorial landscape of Karelia and the way that the history of the Finnish past and war memories are negotiated here. This region experienced the so-called "Winter War," which began with the Soviet offensive on Finland on 30 November 1939. The brutal fighting ended with the annexation of Finnish territories on the Karelian isthmus and in Northern Ladoga region in 1940. The authors show how the official memory of the Great Patriotic War influenced the remembering (or rather, the forgetting) of the Winter War and its victims. They also demonstrate how the end of the Cold War and the break with the Soviet past in the early 1990s affected the monumental memorialization of World War II in this border region.

\section{Coda: From Communicative to Cultural Memory}

We opened this introductory essay with a story about the resurrection of a World War II tank in East Ukraine. In concluding, let us return briefly to the tank-turned-monument-that quintessentially Soviet memorial that illustrates the ubiquity of this particular war memory in everyday life. 
The memorial tank was one of the key symbols of the Soviet Victory myth. Soviet tanks, taken from where they stood once the fighting was over, and then mounted on plinths, were among the first improvised celebratory war memorials to spring up over Eastern Europe. In the early post-war years, one such tank even stood in the center of Vienna as part of the Soviet war memorial at Schwarzenbergplatz. The tank-turnedmonument carried multiple messages. It served as a material reminder of sacrifice, but also of power; as a memorial to the dead of the past, but also a warning for the future to the populations living in the landscapes dotted by these tanks. The standard issue tank was an ideal symbol for the new Soviet Victory myth. An empire that had terrorized its own citizens in the 1930s and then suffered catastrophic loss during World War II needed a single, monolithic legitimizing narrative, and it manufactured one in the myth of the collective heroic Victory.

After the communist bloc collapsed, these memorial tanks were generally removed or desacralized in Central Eastern Europe. ${ }^{14}$ But in our region, these monuments, like the myth of the Great Patriotic War more broadly, retain residual symbolic power. The communist authorities' symbolic investment in the cult of the Great Patriotic War is still reflected today in the problem of the past's perceived "emptiness" without the comfort of the Victory myth-a problem that is specific to post-Soviet space.

While the Soviet Victory myth aimed to homogenize and dichotomize, a closer look uncovers a kaleidoscopic view on the fragments of this myth as they are transformed in their local contexts. If we zoom in on the Estonian border town of Narva today, as Elena Nikiforova does in Chap. 15, we see young couples visiting the local Soviet tank-monument for wedding photos and children decorating the tank with flowers. Here, the tank memorial has been normalized, perhaps perversely, as a symbol of peace.

Meanwhile, in the midst of a new war in Ukraine, new tank memorials have appeared. In the grounds of the national World War II museum in Kyiv, a T-64BV tank, seized by Ukrainian forces in the Donbas in June 2014 and repainted in the colors of the Ukrainian flag, is now displayed as material evidence of the Russian military presence in Ukraine.

And yet if we had to choose a tank-monument that best exemplifies the current moment, we might instead offer up the suggestive example of the tank-monument that was erected in 2010 in Belgorod, in front of the new Museum of Military Glory at the Prokhorovka battlefield. This 
sculptural composition is a life-size rendering of five tanks-two Soviet T-34s and three German "Tigers." Titled "The Ramming", the monument presents the tanks suspended in time, piled up at the moment of the Soviet tanks' deliberate suicide charge. ${ }^{15}$ With its depiction of the suicidal podvig, the monument reproduces a traditional Soviet motif of heroic selfsacrifice. But what is especially interesting about this new memorial is the departure it represents. Unlike the conventional Soviet tank-monument, this is not a real tank but its monumental sculpture; not a military artifact, but a meta-monument-a pure symbol. In this sense, it illustrates the transition from communicative to cultural memory: the re-codification, the re-mythologization of World War II, as the participants of that warbe they live veterans, or real tanks that participated in real battles-depart. In a way, the monument is an allegory of this transition, as we move into the uncertain future of memory in the absence of witnesses.

\section{Notes}

1. On the rush to collect and archive the memories of the last veterans, see also Lassila (2013).

2. The book is one of several collective publications in East European Memory Studies produced by the Memory at War project: Remembering Katyn (Polity 2012); Memory, Conflict and New Media: Web Wars in Post-Socialist States (Routledge 2013); Memory and Theory in Eastern Europe (Palgrave 2013); Martyrdom and Memory (a special issue of the Journal of Soviet and Post-Soviet Politics and Society) (2015); and Contested Interpretations of the Past in Polish, Russian, and Ukrainian Film: Screen as Battlefield (Brill 2016). Memory at War has also resulted in numerous journal articles, and several single-author books, including: Alexander Etkind, Warped Mourning: Stories of the Dead in the Land of the Unburied (Stanford University Press 2013); Tanya Zaharchenko, Where Currents Meet: Frontiers in Post-Soviet Fiction of Kharkiv, Ukraine (Central European University Press 2016); Uilleam Blacker, Memory, Forgetting and the Legacy of Post-1945 Displacement in Russia and Eastern Europe (forthcoming Routledge 2017) -with several more in the pipeline.

3. This is why we saw fit to include a chapter on Russian memory narratives operating in the Estonian city of Narva. The memory project of the "Russian world" is one that is self-consciously aimed at spreading across current national borders, and the case of Narva offers a vivid example of the enduring hold that the Russian/Soviet narrative of the war has in the imagination of the Russian diaspora in post-Soviet space. 
4. In April 2016 school children taking part in the Memorial Society's history essay contest were attacked by nationalists, some of whom were dressed in World War II soldiers' uniforms and playing accordions, and called "fascists"; the police stood by and did not intervene; see Pavlova (2016).

5. See for example the statement by the recently appointed Russian human rights ombudsman Tat'iana Moskal'kova that "human rights" has now become a façade for fascism (cited Obukhov 2016).

6. Etkind commented that:

[Historical] re-enactors must, they are simply obligated to understand the difference between past and present. They're playing at a strange past now. One must understand the difference between play and reality. Between dream and reality. Let them dream and play at their kindergarten. Let reconstruction stay in its place. When all this starts to get confused and mixed up and to become interchangeable, then this is really dangerous.

The refusal to see the difference between [past and] present is a frightening thing. A healthy memory must recognize these differences, [it must] mourn for the past but understand that one can't return to the past. The refusal to recognize this difference, the belief that the past is now returning-this is a pathology. Reconstruction which swallows up the present can bring nothing positive. (cited in Zemtsov 2014)

7. The 2016 Night Wolves show was titled "Ark of Salvation," and featured pyrotechnics, motorbike stunts, and long turgid monologues on historical themes. Prokhanov commented on the show: "There's a lot of fire here, light, music, power, dance. Everything that happens in church is here. In the church that the 'Surgeon' [the head of the Night Wolves] has built, a new reality is being created. Because this 'Fifth Empire' is our Russia today. Our ancient imperial consciousness is being awakened in the young people who watch this show. In this sense the 'Surgeon' is a magician, a wizard, a magus!” (cited Meduza 2016).

8. This is how it was generally reported in the media; Putin's exact words (responding to a question from Night Wolves' head “The Surgeon" as to whether Victory would have been possible had Ukraine and Russia been divided at the time) were:

Now with regard to our relations with Ukraine. I'll permit myself not to agree with what you said just now, that had we not been divided, we would have lost the war. We would have won anyhow, because we are a country of winners. And more than that, there's a definite basis for what I've just said. If we look at the statistics from the World War II period, then it becomes clear that ... the greatest losses in the Great Patriotic War were sustained precisely by the RSFSR-over $70 \%$ of losses. This 
means that the war was won-I don't want to offend anybody, but on the whole, at the expense of resources, human and industrial, resources of the Russian Federation. These are historical facts. This is all in the documents. This by no means detracts from the significance that was played [sic] in the shared victory by the republics of the former Soviet Union. But definitely, when we were together, we represented a much more powerful force.

The video of this exchange is available at https://www.youtube.com/ watch? $=$ BlyiaQ-Z-84.

9. On the Flowers of the Great Victory project see further the Molodezh' Belarusi website: http://brsm.by/projects/tsvety-velikoj-pobedy/. The description here explains that the colors of the apple flower "embody the unbroken bond between generations and sincere gratitude for the herowarriors who gave their children and grandchildren the Great Victory, the opportunity to live, toil, and raise children in peace, and also, as in the unforgettable May of 1945, to rejoice sincerely in the blossoming gardens that have been a symbol of the new peaceful victories of sovereign Belarus.”

10. On the history of the deliberate creation of the notion of an "East Slavic" language branch and its political uses, see Kamusella (2008). See also Kulyk's discussion of the East Slavic/Soviet narrative which posits that Ukraine, Russia, and Belarus comprise a single entity (Kulyk 2013).

11. This is a trend that has been in place for some years now. Militant proKremlin youth organizations such as Nashi rooted their legitimacy in historical issues, using a sacralized version of the history of World War II to justify threats of street violence in the wake of the 2004 Orange Revolution in Ukraine, for example (see Horvath 2013). The state-manufactured NGO World without Nazism movement was created in 2010, and in 2013 the Russian state identified neo-Nazism as "the major challenge of the 21 st century," to cite the title of an international conference organized on this theme in Washington under Russian leadership ("Zasedanie" 2013).

12. Blogger Denis Luzgin was charged for reposting an article that included the statement that "the communists and Germany jointly attacked Poland, unleashing World War II, that is communism and Nazism were honest collaborators." The Russian Supreme Court upheld the ruling that this phrase contradicted "the facts established by the Nuremberg tribunal." See further "Zaiavlenie" (2016).

13. On the post-Soviet fates of Stalin as symbol in the Belarusian context, see Chapter. 8, which explores the new "Stalin Line" outdoor museum near Minsk with its drive to link Stalin to leisure and entertainment, and the Belarusian debates over the figure of Stalin. 
14. In Prague, it has now become a tradition for the local Soviet tank to be painted pink and used to make political and artistic statements of various kinds; in Nowa Huta in Poland, the local tank has come to be accepted by residents as an intrinsic element of the urban landscape (Pozniak 2014).

15. The five-meter high monument is designed to enable the visitor to step inside it so as to view another component of the composition, a human figure: the "despairing [obezumevshii] German soldier," based on a famous 1943 photograph, but "deliberately aged so as to fit in with the general idea of the sculptural composition"; see "Muzei boevoi slavy" (2015) and Gubina (2010). In a comment on another monument erected at the site in 2015 by the same sculptors, the Sogoian brothers, one of them described their aim as "showing how in battle, people and hardware became a united whole and strove for a shared aim" - an observation that perhaps also helps to explain the curiously "alive" nature of the Soviet tank (cited in Knorre-Dmitrieva 2015). The tanks in a recent cinematic depiction of the Prokhorovka tank battle, Shakhnazarov's White Tiger (2012), also resemble living beings, incidentally.

\section{REFERENCES}

Al'tman, I. 2005. “Memorializatsiia Holokosta v Rossii: istoriia, sovremennost', perspektivy." Neprikosnovennyi zapas 2-3 (40-41).

Antonova, Ye. 2014. "Professora uvolili za vzgliady." Gazeta.ru, 24 March. Retrieved 1 Nov 2016 from http://www.gazeta.ru/social/2014/03/24/ 5962589.shtml.

Aptekar', P. 2014. “Istoriki v shtatskom.” Vedomosti, 30 Jan. Retrieved I Nov 2016 from http://www.vedomosti.ru/opinion/news/22065861/ istoriki-v-shtatskom.

Assmann, J. 2008. "Communicative and Cultural Memory." In Cultural Memory Studies: An International and Interdisciplinary Handbook, ed. A. Erll and A. Nünning, 109-118. Berlin and New York: De Gruyter.

Bekus, N. 2016. "Constructing Post-Soviet Space as a 'Remembering Community': Contested Nazi Victimhood after 1989.” European Network Remembrance and Solidarity conference Genealogies of Memory: Memory Regions as Discourse and Imagination, Warsaw, 17-19 March.

Bell, D.S.A. 2003. "Mythscapes: Memory, Mythology, and National Identity." British Journal of Sociology 54 (1): 63-81.

Bratachkin, A. 2015. “'Podz'vihu naroda zhyts' u viakakh': novy Muzei Vialikai Aichynnai vainy iak forma adchuzhen'nia ad history." pARTisan 27: 29-35.

Brunstedt, J. 2011. "Building a Pan-Soviet Past: The Soviet War Cult and the Turn Away from Ethnic Particularism." The Soviet and Post-Soviet Review 38 (2): 149-171. 
Carleton, G. 2016. "Russian Fiction at War." In The Long Aftermath: Cultural Legacies of Europe at War, 1936-2016, ed. M. Bragança and P. Tame, 358372. New York and Oxford: Berghahn Books.

Chistiakov, A. (ed.). 2014. Chasovye pamiati. Moscow: Obshchestvennyi sovet "Potentsial natsii" and IPO "U nikitskikh vorot."

Corney, F.C. 2004. Telling October: Memory and the Making of the Bolshevik Revolution. Ithaca, NY: Cornell University Press.

Darenskii, V. 2015. "Odesskaia tragediia kak simvol sovremennoi Ukrainy.” Novoross.info, 6 May. Retrieved 7 Nov 2016 from http://www.novoross.info/ general/31589-odesskaya-tragediya-kak-simvol-sovremennoy-ukrainy.html.

Dubin, B. 2005. "Pamiat', voina, pamiat' o voine. Konstruirovanie proshlogo v sotsial'noi praktike poslednikh desiatiletii." Otechestvennye zapiski 4 (43).

Etkind, A. 2013. Warped Mourning: Stories of the Undead in the Land of the Unburied. Stanford, CA: Stanford University Press.

Etkind, A., R. Finnin, U. Blacker, J. Fedor, S. Lewis, M. Mälksoo, and M. Mroz. 2012. Remembering Katyn. Cambridge: Polity Press.

Fedor, J. 2015. "Introduction: Russian Media and the War in Ukraine." Journal of Soviet and Post-Soviet Politics and Society 1 (1): 1-12.

Gabowitsch, M. 2015. "Pamiatnik i prazdnik: etnografiia 9 maia." Neprikosnovennyi zapas 3 (101).

Gabowitsch, M., C. Gdaniec, and E. Makhotina (eds.). 2016. Kriegsgedenken als Event. Der 9.Mai 2015 im postsocialistischen Europa. Padeborn: Verlag Ferdinand Schönlingh.

Grachova, S. 2008. "Unknown Victims: Ethnic-Based Violence of the World War II Era in Ukrainian Politics of History after 2004." Fourth Annual Danyliw Research Seminar in Contemporary Ukrainian Studies, Chair of Ukrainian Studies, Oct 23-25, in University of Ottawa, Canada.

Grinevich, V. 2005. "Raskolotaia pamiat': Vtoraia mirovaia voina v istoricheskom soznanii ukrainskogo obshchestva." Neprikosnovennyi zapas 40-41. Retrieved 9 Jan 2017 from http://magazines.russ.ru/nz/2005/2/gri24.html.

Gubina, S. 2010. “Taran' poiavilsia na Prokhorovskom pole.” bel.ru, 16 April. Retrieved 14 Nov 2016 from http://www.bel.ru/news/region/45673.html.

Gudkov, L. 2005. “Pamiat" o voine i massovaia identichnost' rossiian." Neprikosnovennyi zapas 2-3 (40-41).

Horvath, R. 2013. Putin's Preventive Counter-Revolution: Post-Soviet Authoritarianism and the Spectre of Velvet Revolution. Abingdon: Routledge.

Huyssen, A. 2003. Present Pasts: Urban Palimpsests and the Politics of Memory. Stanford, CA: Stanford University Press.

Kamusella, T. 2008. The Politics of Language and Nationalism in Modern Central Europe. Basingstoke: Palgrave Macmillan.

Kappeler, A. 1997. "Mazepintsy, malorossy, khokhly: ukraintsy v etnicheskoi ierarkhii Rossiiskoi Imperii." In Rossiia-Ukraina: istoriia vzaimootnoshenii, 
ed. A.I. Miller, V.F. Reprintsev, and B.N. Floria, 125-144. Moscow: Shkola "Yazyki russkoi kul'tury."

Kashin, O. 2016. "Novyi prazdnik novogo naroda." rus2web.ru, 6 May. Retrieved 14 Nov 2016 from http://rus2web.ru/speczmaterialyi/novyijprazdnik-novogo-naroda.html.

Kasianov, G. 2014. "How History Goes Wrong: Historical Politics and its Outcomes." Cultural Anthropology, 28 Oct. Retrieved on 24 July 2016 from https://culanth.org/fieldsights/611-how-history-goes-wrong-historical-politics-and-its-outcomes.

Khanin, V. 2015. "Baik-shou 'Nochnykh volkov's razmakhom proshlo v Sevastopole." REN TV, 22 Aug. Retrieved 26 Aug 2016 from http://ren.tv/novosti/2015-08-22/bayk-shou-nochnyh-volkovs-razmahom-proshlo-v-sevastopole-video.

Knorre-Dmitrieva, K. 2015. "Voevavshim pod Prokhorovkoi." Novaia gazeta, 16 May. Retrieved 14 Nov 2016 from https://www.novayagazeta.ru/ articles/2015/05/16/64146-voevavshim-pod-prohorovkoy.

Kosterina, I. 2015. "My u proshlogo ne uchimsia, my im zhivem." Neprikosnovennyi zapas 4 (102). Retrieved 26 July 2016 from http://magazines.russ.ru/nz/2015/4/1 lint.html.

Kotkin, S. 1995. Magnetic Mountain: Stalinism as a Civilization. Berkeley and Los Angeles, CA: University of California Press.

Kulyk, V. 2013. "War of Memories in the Ukrainian Media: Diversity of Identities, Political Confrontation, and Production Technologies." In Memory, Conflict and New Media: Web Wars in Post-Socialist States, ed. E. Rutten, J. Fedor, and V. Zvereva, 63-81. Abingdon: Routledge.

Kulyk, V. 2014. "Ukrainian Nationalism since the Outbreak of Euromaidan." $A b$ Imperio 4: 94-122.

Lassila, J. 2013. "Witnessing War, Globalizing Victory: Representations of the Second World War on the Website Russia Today." In Memory, Conflict and New Media: Web Wars in Post-Socialist States, ed. E. Rutten and J. Fedor, 215-227. Abingdon: Routledge.

Lastovskii, A., L. Mikheeva, and A. Bratochkin. 2014. "Kriticheskii vzgliad na novyi muzei Velikoi Otechestvennoi voiny v Minske." Novaia Europa, 28 Aug. Retrieved 24 Oct 2016 from http://n-europe.eu/article/2014/08/25/kriticheskii_vzglyad_na_novyi_muzei_velikoi_otechestvennoi_voiny_v_minske.

Levinson, A. 2015. "Voina kak proshloe i kak budushchee." Neprikosnovennyi zapas 101 (3). Retrieved 14 Nov 2016 from http://nlobooks.ru/ node/6369.

Levy, D., and N. Sznaider. 2002. "Memory Unbound: The Holocaust and the Formation of Cosmopolitan Memory." European Journal of Social Theory 5: 87-106. 
Lewis, S. 2015. "Khatyn and its Discontents: Hegemonic Martyrdom and deSovietization in Belarus." Journal of Soviet and Post-Soviet Politics and Society 1 (2): 367-401.

Maevskaia, Ya. 2009. "Komu i zachem nado porochit' istoriiu Rossii." Vecherniaia Moskva 246, 29 Dec.

Marples, D.R. 1994. "Kurapaty: The Investigation of a Stalinist Historical Controversy." Slavic Review 53: 513-523.

Marples, D.R. 2003. "History and Politics in Post-Soviet Belarus. The Foundations." In Contemporary Belarus: Between Democracy and Dictatorship, ed. E.A. Korosteleva, C.W. Lawson, and R.J. Marsh, 21-35. London and New York: Routledge Curzon.

Marples, D.R. 2012. "History, Memory, and the Second World War in Belarus." Australian Journal of Politics \& History 58: 437-448.

Marples, D.R. 2014. "Our Glorious Past": Lukashenka's Belarus and the Great Patriotic War. Stuttgart: ibidem-Verlag.

Marples, D.R. 2015. "Open Letter from Scholars and Experts on Ukraine Re the So-Called 'Anti-Communist Law."' April. Retrieved 24 July 2016 from http://krytyka.com/en/articles/open-letter-scholars-and-experts-ukraine-reso-called-anti-communist-law.

Meduza. 2016. "Piataia imperiia i okamenevshie sklepy." Meduza.io, 17 Aug. Retrieved 26 Aug 2016 from https://meduza.io/shapito/2016/08/17/ pyataya-imperiya-i-okamenevshie-sklepy.

Miller, A. 2016. "Politika pamiati v postkommunisticheskoi Yevrope i yee vozdeistvie na yevropeiskuiu kul'turu pamiati." gefter.ru, 29 April. Retrieved 24 July 2016 from http://gefter.ru/archive/18391.

Miller, A., and M. Lipman. 2012. The Convolutions of Historical Politics. Budapest: Central European University Press.

Mitrokhin, N. 2015. "Infiltration, Instruction, Invasion: Russia's War in the Donbass." Journal of Soviet and Post-Soviet Politics and Society l (1): 219-249.

Müller, J.-W. (ed.). 2002. Memory and Power in Post-War Europe: Studies in the Presence of the Past. Cambridge: Cambridge University Press.

"Muzei boevoi slavy." 2015. vidania.ru, 4 Nov. Retrieved 14 Nov 2016 from http://www.vidania.ru/temple/temple_belgorodskaya/prohorovka_muzey_ boevoy_slavy.html.

Norris, S.M. 2011. "Memory for Sale: Victory Day 2010 and Russian Remembrance." The Soviet and Post-Soviet Review 38 (2): 201-229.

Obukhov, A. 2016. "Novyi general-ombudsmen Moskal'kova reshila srazhat'sia s Zapadom v pravozashchitnoi sfere." Moskovskii komsomolets, 22 April. Retrieved 25 April 2016 from http://www.mk.ru/politics/2016/04/22/ novyy-generalombudsmen-moskalkova-reshila-srazhatsya-s-zapadom-v-pravozashhitnoy-sfere.html. 
Ochman, E. 2009. "Municipalities and the Search for the Local Past. Fragmented Memory of the Red Army in Upper Silesia." East European Politics and Societies 23 (3): 392-420.

Olick, J.K. 2015. "Foreword." In Memory and Change in Europe: Eastern Perspectives, ed. M. Pakier and J. Wawrzyniak, ix-xii. New York and Oxford: Berghahn Books.

"Patriarch." 2000. “The Patriarch of Moscow and all the Rus' Alexi II and the presidents of Russia, Ukraine and Belarus visited Belgorod and Prokhorovka." The Russian Orthodox Church. The official site of the Department for the External Church Relations, 17 May. Retrieved 25 July 2016 from www.mospat.ru/archive/nr005172.htm.

Pavlova, S. 2016. "Provokatsiia pod prismotrom politsii." Radio Svoboda, 28 April. Retrieved 18 Aug 2016 from http://www.svoboda.org/a/27704522.html.

Portnov, A. 2016. "Bandera Mythologies and Their Traps for Ukraine." openDemocracy Russia and beyond, 22 June. Retrieved 24 July 2016 from https://www.opendemocracy.net/od-russia/andrii-portnov/banderamythologies-and-their-traps-for-ukraine.

Pozniak, K. 2014. Nowa Huta: Generations of Change in a Model Socialist Town. Pittsburgh, PA: University of Pittsburgh Press.

Rothberg, M. 2009. Multidirectional Memory: Remembering the Holocaust in the Age of Decolonization. Stanford, CA: Stanford University Press.

Rozhdestvenskaya, E. 2015. "Review of E.S. Seniavskaia’s Istoriia Voin.” Journal of Soviet and Post-Soviet Politics and Society 1 (2): 467-473.

Rudling, P.A. 2008. "'For a Heroic Belarus!': The Great Patriotic War as Identity Marker in the Lukashenka and Soviet Belarusian Discourses." Sprawy Narodowościowe 32: 43-62.

Rudling, P.A. 2012. "The Khatyn Massacre in Belorussia: A Historical Controversy Revisited." Holocaust and Genocide Studies 26: 29-58.

Savchenko, N. 2014. "V Sevastopole proshlo baik-shou "Vozvrashchenie."” Rossiiskaia gazeta, 9 Aug. Retrieved 26 Aug 2016 from https:// rg.ru/2014/08/09/reg-kfo/baikery.html.

Segodnia. 2014. "V Konstantinovke separatist 'ozhivili' tank-pamiatnik." Segodnia. ua, 5 June. Retrieved 14 Nov 2016 from http://www.segodnya.ua/regions/ donetsk/v-konstantinovke-separatisty-ozhivili-tank-pamyatnik-526553.html.

Shevel, O. 2011. "The Politics of Memory in a Divided Society: A Comparison of Post-Franco Spain and Post-Soviet Ukraine." Slavic Review 70 (1): $137-164$.

Snyder, T. 2010. Bloodlands: Europe between Hitler and Stalin. New York: Basic Books.

Sova. 2014. "Podpisan zakon 'O reabilitatsii natsizma." Informatsionnoanaliticheskii tsentr "SOVA," 5 May. Retrieved 14 Nov 2016 from http:// www.sova-center.ru/misuse/news/lawmaking/2014/05/d29466/. 
Stan, L. (ed.). 2008. Transitional Justice in Eastern Europe and the Former Soviet Union: Reckoning with the Communist Past. Abingdon: Routledge.

Steinberg, M.D. 2014. "Emotions History in Eastern Europe." In Doing Emotions History, ed. S.J. Matt and P.N. Stearns, 74-99. Urbana, IL: University of Illinois Press.

Tismaneanu, V., et al. (eds.). 2010. Politics of Memory in Post-Communist Europe. Bucharest: Zeta Books.

Tumarkin, N. 1994. The Living and the Dead: The Rise and Fall of the Cult of World War II in Russia. New York: Basic Books.

Waligórska, M. 2016. "Jewish Heritage and the New Belarusian National Identity Project." East European Politics and Societies and Cultures 30: 332-359.

Weiner, A. 2001. Making Sense of War: The Second World War and the Fate of the Bolshevik Revolution. Princeton, NJ: Princeton University Press.

Winter, J. 2010. "The Performance of the Past: Memory, History, Identity." In Performing the Past: Memory, History, and Identity in Modern Europe, ed. K. Tilms, F. van Vree, and J. Winter, 11-23. Amsterdam: Amsterdam University Press.

Winter, J. 2013. "Human Rights and European Remembrance." In Memory and Theory in Eastern Europe, ed. U. Blacker, A. Etkind, and J. Fedor, 43-58. New York: Palgrave Macmillan.

Wolfe, T.C. 2006. "Past as Present, Myth, or History? Discourses of Time and the Great Fatherland War." In The Politics of Memory in Postwar Europe, ed. R.N. Lebow, W. Kansteiner, and C. Fogu, 249-283. Durham, NC: Duke University Press.

Yekelchyk, S. 2004. Stalin's Empire of Memory: Russian-Ukrainian Relations in the Soviet Historical Imagination. Toronto and Buffalo: University of Toronto Press.

Yekelchyk, S. 2015. The Conflict in Ukraine. What Everyone Needs to Know. New York and Oxford: Oxford University Press.

“Zaiavlenie.” 2016. “Zaiavlenie Vol'nogo istoricheskogo obshchestva v sviazi s prigovorom Denisu Luzginu." Vol’noe Istoricheskoe Obshchestvo website, 5 Sept. Retrieved 7 Sept 2016 from http://volistob.ru/statements/zayavlenievolnogo-istoricheskogo-obshchestva-v-svyazi-s-prigovorom-denisu-luzginu.

“Zasedanie." 2013. "Zasedanie Rossiiskogo organizatsionnogo komiteta 'Pobeda.'" Russian President's official website, 12 July. Retrieved 15 April 2015 from http://www.kremlin.ru/transcripts/18714.

Zemtsov, A. 2014. “Aleksandr Etkind: 'Rekonstruktory seichas igraiut v strannoe proshloe." Svobodnye Novosti Volga, 7 Oct. Retrieved 25 Aug 2016 from http://fn-volga.ru/newspaperArticle/view/id/2854.

Zhurzhenko, T. 2014. "A Divided Nation? Reconsidering the Role of Identity Politics in the Ukraine Crisis." Die Freidenswarte 8 (1-2): 249-267. 
Zhurzhenko, T. 2015a. "Russia's Never-ending War against 'Fascism."” Eurozine, 8 May. Retrieved 18 Aug 2016 from http://www.eurozine.com/ articles/2015-05-08-zhurzhenko-en.html.

Zhurzhenko, T. 2015b. "Shared Memory Culture? Nationalizing the 'Great Patriotic War' in the Ukrainian-Russian Borderlands." In Memory and Change in Europe: Eastern Perspectives, ed. M. Pakier and J. Wawrzyniak, 169-192. New York and Oxford: Berghahn Books.

Open Access This chapter is licensed under the terms of the Creative Commons Attribution 4.0 International License (http://creativecommons.org/licenses/ by $/ 4.0 /$ ), which permits use, sharing, adaptation, distribution and reproduction in any medium or format, as long as you give appropriate credit to the original author(s) and the source, provide a link to the Creative Commons license and indicate if changes were made.

The images or other third party material in this chapter are included in the chapter's Creative Commons license, unless indicated otherwise in a credit line to the material. If material is not included in the chapter's Creative Commons license and your intended use is not permitted by statutory regulation or exceeds the permitted use, you will need to obtain permission directly from the copyright holder.

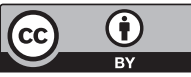

